\title{
PERBANDINGAN HASIL BELAJAR MATEMATIKA SISWA MENGGUNAKAN PENDEKATAN MATEMATIKA REALISTIK DAN PENDEKATAN SAINTIFIK DI KELAS VII SMP NEGERI 14 KOTA BENGKULU
}

\author{
Bet Sri Anita Sari ${ }^{1}$, Syafdi Maizora ${ }^{2}$, dan Hanifah $^{3}$ \\ Program Studi Pendidikan Matematika, FKIP Universitas Bengkulu \\ email : ${ }^{1}$ betsri.bas@gmail.com, ${ }^{2}$ syafdiichiemaizora@unib.ac.id, ${ }^{3}$ hanifah@unib.ac.id
}

\begin{abstract}
ABSTRAK
Penelitian ini bertujuan untuk mengetahui apakah hasil belajar peserta didik yang menggunakan Pendekatan Matematika Realistik (PMR) lebih dari hasil belajar peserta didik yang menggunakan pendekatan Saintifik. Penelitian ini merupakan penelitian eksperimen semu dengan populasi seluruh peserta didik kelas VII SMPN 14 Kota Bengkulu Semester Genap Tahun Ajaran 2017/2018. Instrumen yang digunakan untuk pengumpulan data dalam penelitian ini adalah lembar tes. Sampel diambil menggunakan teknik purposive sampling sehingga diperoleh kelas VII 1 sebagai kelas eksperimen dengan peserta didik yang berjumlah 29 peserta didik yang mendapat perlakuan Pendekatan Matematika Realistik (PMR) dan kelas VII 2 sebagai kelas kontrol dengan peserta didik yang berjumlah 29 peserta didik yang mendapat perlakuan Pendekatan Saintifik. Berdasarkan hasil analisis data yang menggunakan Uji-t diperoleh nilai sig. 2 (tailed) yaitu 0,003 dengan taraf nyata $(\alpha)=5 \%$, sehingga nilai sig.2(tailed $)<\alpha$. Oleh karena itu, dapat disimpulkan bahwa hasil belajar matematika siswa menggunakan Pendekatan Matematika Realistik (PMR) lebih tinggi dari hasil belajar matematika siswa yang menggunakan Pendekatan Saintifik di kelas VII SMPN 14 Kota Bengkulu.
\end{abstract}

Kata Kunci: Hasil belajar matematika, Pendekatan Matematika Realistik, Pendekatan Saintifik.

\begin{abstract}
This research was aimed at investigating whether of the students learning result using Realistic Mathematic Approach more than students learning result using Scientific Approach. This research was quasi-experimental and the total population were the entire students of Grade VII Junior High School 14 Bengkulu, odd semester academic year of 2017/2018. The instrument used for data collection in this study is a test sheet. The samples were collected by using purposive sampling technique in that there were the class of VII 1 as the experiment one with total students of 29 treated by Realistic Mathematic Approach and the class of VII 2 as the control class with the total students of 29 treated by Scientific Approach. Based on the data analysis using t-test were found sig.2(tailed) 0,003 with the significance level $(\alpha)=5 \%$, hence the sig.2(tailed) $<\alpha$. Therefore, it could be concluded that the result of learning mathematics student used realistic mathematics approach more than the result of learning mathematics student used Scientific approach in class VII SMPN 14 Bengkulu.
\end{abstract}

Keyword: Result of learning mathematics, Realistic Mathematics approach, Scientific approach

\section{PENDAHULUAN}

Pendidikan Matematika merupakan salah satu pendidikan dasar dan merupakan mata pelajaran wajib yang diajarkan di sekolah. Matematika diajarkan pada setiap jenjang pendidikan, mulai dari pendidikan dasar sampai pendidikan tinggi. Matematika merupakan suatu cabang ilmu yang memegang peran penting dalam kehidupan manusia. Pembelajaran matematika di sekolah memiliki tujuan agar siswa menjadi manusia yang siap untuk menghadapi perubahan zaman. Seperti yang kita ketahui bahwa dari tahun ke tahun dunia selalu mengalami perubahan, untuk siap menghadapi perubahan itu maka salah satunya siswa wajib mempelajari matematika, karena matematika merupakan mata pelajaran yang berhubungan dengan logika, kritis, dan rasoinal. Setelah mempelajari matematika siswa diharapkan mampu mengaplikasikannya ke dalam kehidupan sehari-hari.

Sayangnya pembelajaran matematika di sekolah mengalami permasalahan. Masih saja ada siswa yang beranggapan bahwa matematika merupakan mata pelajaran yang menyeramkan, sulit dimengerti, dan banyak lagi tanggapan yang lainnya. Hasil penelitian Wahyu Widada di Propinsi Bengkulu ditemukan bahwa pembelajaran matematika di sekolah-sekolah sangat teoritis, text book oriented, tidak terkait dengan kehidupan sehari-hari siswa, dan tidak terkait dengan previous schema yang ada dalam perkembangan siswa Bengkulu (Herawaty, 2016: 43). Siswa juga tidak 
mengetahui manfaat pembelajaran matematika dalam kehidupan nyata atau kehidupan mereka sehari-hari, hal inilah yang menyebabkan mereka malas untuk memahami materi-materi dalam pembelajaran matematika.

Berdasarkan hasil observasi selama melaksanakan magang di SMP Negeri 14 Kota Bengkulu, terlihat masih banyak siswa yang ribut dan asyik mengobrol tanpa memperhatikan guru yang sedang memberikan materi pembelajaran. Tidak sampai setengah dari jumlah siswa di kelas yang memperhatikan guru menyampaikan materi. Hal ini mengakibatkan banyaknya siswa yang memperoleh hasil belajar di bawah nilai KKM. Hasil belajar adalah kemampuan-kemampuan yang dimiliki siswa setelah ia menerima pengalaman belajarnya (Sudjana, 2011:22).

Berdasarkan hasil wawancara pada tanggal 11 Januari 2018 salah satu guru matematika di kelas VII, beliau mengatakan bahwa hasil belajar siswa pada ulangan semester ganjil masih banyak sekali siswa yang mendapatkan nilai di bawah nilai KKM, yaitu 75. Ada 6 kelas di kelas VII pada SMP N 14 Kota Bengkulu ini dan setiap kelas tersebut mendapatkan nilai yang homogen pada Ulangan Semester Ganjil, dan siswa yang nilainya tuntas hanya sedikit. Pada kelas VII.1 misalnya, hanya 4 dari 30 siswa yang mendapatkan nilai ulangan semester ganjilnya berada di atas nilai KKM.

SMP Negeri 14 Kota Bengkulu telah menerapkan kurikulum 2013 pada semua kelas VII. Seperti yang telah diketahui bahwa kurikulum 2013 ini menggunakan pendekatan Saintifik. Pendekatan saintifik adalah pendekatan pembelajaran yang memberikan kesempatan kepada peserta didik untuk mendapat pengalaman belajar melalui mengamati, menanya, mengumpulkan informasi, mengasosiasi dan mengomunikasikan (Daryanto dan Syaiful Karim, 2017: 41). Pendekatan saintifik yang menjadi pusat pembelajaran adalah siswa, sehingga siswa dituntut untuk lebih aktif selama proses pembelajaran berlangsung. Kenyataannya, proses pembelajaran yang terjadi pada kelas yang saya observasi terlihat hanya ada beberapa siswa yang aktif mengikuti proses pembelajaran. Siswa yang lain juga aktif saat proses pembelajaran berlangsung, hanya saja mereka aktif mengobrol dengan temannya bukan aktif mengikuti pembelajaran.

Solusi yang dapat dilakukan salah satunya adalah dengan menggunakan pendekatan pembelajaran yang tepat sehingga apa yang diharapkan guru dapat tercapai. Terdapat banyak sekali pendekatan yang dapat digunakan dalam pembelajaran matematika, salah satunya yakni pendekatan matematika realistik. Pendidikan Matematika Realistik adalah suatu pendekatan pembelajaran matematika yang harus selalu menggunakan masalah sehari-hari. (Ariyadi Wijaya, 2012 : 20). Pendekatan matematika realistik dapat membuat siswa mengetahui kegunaan dalam mempelajari materi matematika dalam kehidupan sehari-hari, sehingga siswa lebih termotivasi untuk mempelajari matematika. Pembelajaran yang dikaitkan langsung dengan kehidupan siswa membuat siswa mengetahui manfaat mempelajari materi yang disampaikan oleh guru. Pemilihan Pendekatan Matematika Realistik penelitian sebelumnya oleh Hanggara dan Suhardi (2016), Zaini dan Marsigit (2014), serta Deden Rizki Pranata (2015).

Penggunaan pendekatan matematika realistik dapat membuat siswa lebih aktif dan termotivasi dalam proses pembelajaran sehingga membuat hasil belajarnya menjadi lebih baik. Berdasarkan uraian di atas, maka peneliti tertarik untuk melakukan penelitian yang berjudul "Perbandingan Pendekatan Matematika Realistik (PMR) dengan Pendekatan Saintifik Ditinjau dari Hasil Belajar Matematika Siswa di Kelas VII SMP Negeri 14 Kota Bengkulu".

\section{METODE PENELITIAN}

Penelitian ini merupakan penelitian Quasi experiment atau eksperimen semu. Populasi pada penelitian ini adalah peserta didik kelas VII semeseter genap SMP Negeri 14 Kota Bengkulu tahun ajaran 2017/2018. Teknik pengambilan sampel pada penelitian ini adalah purposive sampling. Purposive sampling adalah teknik penentuan sampel dengan pertimbangan tertentu (Lestari dan Yudhanegara, 2017:110). Pada penelitian ini sampel dipilih berdasarkan nilai ratarata nilai ulangan matematika pada semester ganjil kelas VII SMP Negeri 11 Kota Bengkulu tahun pelajaran 2017/2018.

Sampel dalam penelitian ini adalah kelas VII 1 sebagai kelas eksperimen yang menggunakan Pendekatan Matematika Realistik dan kelas VII 2 sebagai kelas kontrol yang menggunakan Pendekatan Saintifik. Kelas yang diambil adalah kelas yang mempunyai nilai rata-rata tidak jauh berbeda yaitu kelas VII 1 dan kelas VII 2 . Kemudian pada penelitian ini juga menggunakan 
kelas uji coba, yaitu kelas VII 3. Kelas uji coba digunakan sebagai kelas uji coba soal posttest.

Instrumen yang digunakan pada penelitian ini berupa lembar tes. Lembar tes tersebut berupa soalsoal uraian yang digunakan sebagai soal posttest untuk mengetahui hasil belajar peserta didik. Pada penelitian ini, soal yang digunakan sebagai instrumen penelitian terlebih dahulu divalidasi dengan uji ahli- Kemudian untuk instrumen soal posttest diuji cobakan pada kelas uji coba. Hasil uji coba tersebut dianalisis berdasarkan uji validitas, uji reliabilitas, uji tingkat kesukaran dan uji daya beda soal, kemudian dipilih soal yang dianggap baik untuk digunakan pada posttest.

Teknik uji validitas yang digunakan pada penelitian ini adalah uji korelasi product moment pearson. Rumus korelasi product moment sebagai berikut:

$$
r_{x y}=\frac{N \sum X Y-\left(\sum X\right)\left(\sum Y\right)}{\sqrt{\left\{N \sum X^{2}-\left(\sum X\right)^{2}\right\}\left\{N \sum Y^{2}-\left(\sum Y\right)^{2}\right\}}}
$$

(Arikunto, 2013:87)

Soal dikatakan valid apabila $0,40<r_{x y} \leq$ 1,00. Untuk menguji reliabilitas tes hasil belajar digunakan rumus Alpha Cronbach sebagai berikut :

$$
r_{11}=\left(\frac{n}{(n-1)}\right)\left(1-\frac{\sum s_{i}^{2}}{s_{t}^{2}}\right)
$$

(Lestari \& Yudhanegara, $2017: 206$ )

Soal dikatakan reliabel apabila $0,40<r_{11} \leq$ 1,00 . Uji daya pembeda soal menggunakan rumus sebagai berikut:

$$
\left(D P=\frac{\bar{X}_{A}-\bar{X}_{B}}{\mathrm{SMI}}\right)
$$

(Lestari \& Yudhanegara, 2017 : 217)

Soal dapat digunakan apabila memenuhi daya beda $0,20<D P \leq 1,00$. Uji taraf kesukaran menggunakan rumus sebagai berikut:

$$
I K=\frac{\bar{X}}{S M I}
$$

(Lestari \& Yudhanegara, 2017 : 224)

Soal dapat digunakan apabila memenuhi tingkat kesukaran $0,70<I K \leq 0,30$.

Data diperoleh dari nilai posttest pada kelas uji coba. Dari 6 soal yang di uji cobakan diperoleh data sebagai berikut:

Table 1 Hasil Uji Tingkat Kesukaran

\begin{tabular}{|c|c|c|}
\hline Butir Soal & Indeks Kesukaran & Ket \\
\hline 1 & 0,61 & Sedang \\
\hline 2 & 0,46 & Sedang \\
\hline 3 & 0,70 & Sedang \\
\hline
\end{tabular}

\begin{tabular}{|c|c|c|}
\hline 4 & 0,48 & Sedang \\
\hline 5 & 0,25 & Sukar \\
\hline 6 & 0,30 & Sedang \\
\hline
\end{tabular}

Pada table 1 di atas terlihat bahwa soal nomor 1, 2, 3, 4, dan 6 berada pada tingkat kesukaran sedang, sehingga soal-soal tersebut dapat langsung digunakan.

Soal nomor 5 berada pada tingkat kesukaran sukar. Sehingga soal nomor 5 tetap dapat digunakan dengan beberapa revisi.

\section{HASIL DAN PEMBAHASAN}

Penelitian dilaksanakan mulai tanggal 2 April sampai dengan 11 Mei 2018 di SMP Negeri 14 Kota Bengkulu. Penelitian ini terdiri dari 6 pertemuan materi dan 1 pertemuan posttest untuk setiap kelas sampel, baik kelas eksperimen maupun kelas kontrol.

Berdasarkan data posttest peserta didik diperoleh hasil sebagai berikut:

\section{Tabel 1 Analisis Deskriptif Hasil Belajar Kelas} Eksperimen

\begin{tabular}{|l|c|}
\hline \multicolumn{1}{|c|}{ Deskripsi } & Indeks \\
\hline Jumlah siswa & 29 \\
\hline Rata-rata nilai & 79,7931 \\
\hline Nilai tertinggi & 100 \\
\hline Nilai terendah & 48 \\
\hline Standar deviasi & 15,31195 \\
\hline Varians & 234,456 \\
\hline
\end{tabular}

Dari tabel 1 diketahui bahwa rata-rata nilai posttest peserta didik pada kelas eksperimen adalah 79,7931. Hal ini diketahui bahwa rata-rata nilai posttest siswa yang melaksanakan pembelajaran menggunakan Pendekatan Matematika Realistik (PMR) berada di atas kriteria ketuntasan minimal (KKM) yang ditetapakan yaitu 75 .

Posttest yang dilakukan dikelas kontrol diikuti oleh 29 orang siswa. Berdasarkan data posttest peserta didik diperoleh hasil sebagai berikut:

Tabel 2 Analisis Deskriptif Hasi Belajar Kelas Kontrol

\begin{tabular}{|l|c|}
\hline \multicolumn{1}{|c|}{ Deskripsi } & Indeks \\
\hline Jumlah siswa & 29 \\
\hline Rata-rata nilai & 65,1034 \\
\hline Nilai tertinggi & 100 \\
\hline Nilai terendah & 30 \\
\hline Standar deviasi & 20,64728 \\
\hline Varians & 426,310 \\
\hline
\end{tabular}

Dari tabel 2 diketahui bahwa rata-rata nilai posttest siswa pada kelas kontrol adalah 65,1034. 
Hal ini diketahui bahwa rata-rata nilai posttest siswa yang melaksanakan pembelajaran menggunakan Pendekatan Saintifik berada di bawah kriteria ketuntasan minimal (KKM) yang ditetapakan yaitu 75 .

Dari rata-rata nilai kedua kelas sampel dapat diketahui bahwa kelas eksperimen memiliki ratarata yang lebih tinggi dari pada kelas kontrol.

Uji normalitas data dilakukan menggunakan software SPSS versi 23 dengan melihat nilai sig pada Kolmogorov-Smirnov dan taraf signifikan = 0,05 atau 5\%. Data hasil posttest pada penelitian ini berdistribusi normal karena nilai sig > taraf signifikan $(\alpha)$.

Berikut ini tabel uji distribusi normalitas data :

Tabel 3 Hasil Uji Normalitas

\begin{tabular}{|c|c|c|c|}
\hline Kelas & sig & Kriteria & Keterangan \\
\hline Eksperimen & 0,076 & 0,05 & $\mathrm{H}_{0}$ diterima \\
\hline Kontrol & 0,225 & 0,05 & $\mathrm{H}_{0}$ diterima \\
\hline
\end{tabular}

Tabel 3 diatas menunjukkan bahwa data hasil postes pada kedua kelas sampel berdistribusi normal, karena nilai sig yang diperoleh lebih dari nilai $\alpha$.

Uji homogenitas data dilakukan menggunakan aplikasi SPSS versi 23 dengan taraf sinifikan $(\alpha)$ adalah 0,05 diperoleh hasil seperti berikut ini :

\section{Tabel 4 Hasil Uji Homogenitas}

\begin{tabular}{|c|c|c|}
\hline sig & Kriteria & Keterangan \\
\hline 0,126 & 0,05 & Data homogen \\
\hline
\end{tabular}

Tabel 4 di atas menunjukkan bahwa nilai sig > $\alpha$, hal ini berarti bahwa data kedua kelas sampel adalah homogen.

Setelah dilakukan uji t-test untuk sampel independen dengan bantuan SPSS, diperoleh rekap hasil sebagai berikut :

Tabel 5 Hasil Uji Hipotesis

\begin{tabular}{|c|c|c|}
\hline $\begin{array}{c}\alpha \text { (Taraf } \\
\text { Signifikan) }\end{array}$ & $\begin{array}{c}\text { Sig. (2- } \\
\text { tailed) }\end{array}$ & Keterangan \\
\hline 0,05 & 0,003 & $\begin{array}{c}\mathrm{H}_{0} \text { ditolak dan } \mathrm{H}_{1} \\
\text { diterima }\end{array}$ \\
\hline
\end{tabular}

Pada tabel 5, dapat dilihat bahwa sig. (2-tailed) $<\alpha$, maka $\mathrm{H}_{0}$ ditolak. Sehingga dapat disimpulkan bahwa hasil belajar matematika siswa yang menggunakan Pendekatan Matematika Realistik (PMR) lebih dari hasil belajar matematika siswa yang menggunakan pendekatan Saintifik di kelas VII SMP Negeri 14 Kota Bengkulu.

Kegiatan mengamati baik di kelas eksperimen maupun kelas kontrol sama-sama dilakukan siswa secara berkelompok, hanya saja perbedaan terdapat pada apa yang mereka amati. Kegiatan mengamati kelas kontrol adalah siswa mengamati tabel yang terdapat pada LKPD sepertiyang terlihat pada gambar 4.6, sedangkan kegiatan mengamati pada kelas eksperimen adalah siswa mengamati masalah kontekstual yang terdapat pada LKPD seperti yang terlihat pada gambar 4.5. Kegiatan mengamati pada kelas eksperimen dan kelas kontrol dapat dilihat pada gambar di bawah ini :

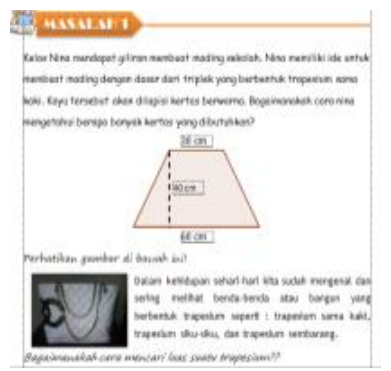

Gambar 1 Objek Pengamatan Kelas Eksperimen Kegiatan mengamati kelas eksperimen difokuskan langsung pada masalah yang berhubungan dengan kehidupan sehari-hari seperti yang terlihat pada gambar 1 di atas. Masalah yang difokuskan langsung dengan kehidupan sehari-hari ini dapat membuat siswa lebih mudah dalam memahami materi pelajaran yang sedang mereka pelajari.

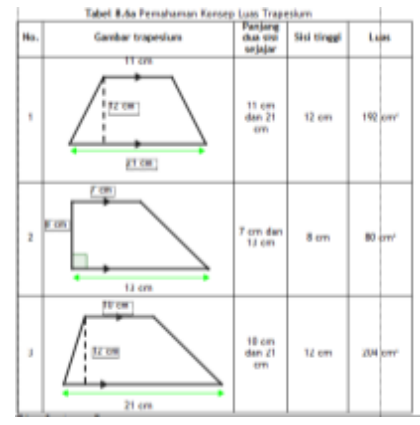

\section{Gambar 2 Hasil Kegiatan Mengamati Kelas Kontrol}

Pada gambar 2 di atas terlihat bahwa kegiatan mengamati pada kelas kontrol langsung pada tabel pemahaman konsep luas dari suatu segiempat. Gambar di atas memperlihatkan hasil kegiatan mengamati siswa ntuk memahami konsep luas dari suatu trapesium yang memiliki bentuk yang berbeda-beda.

Kegiatan berbagi informasi, salah satu kelompok siswa pada kelas kontrol ditunjuk guru maju ke depan untuk memaparkan hasil dikusi kelompoknya ke depan kelas. Setelah siswa berbagi informasi guru bersama siswa menyimpulkan hasil pembelajaran. 


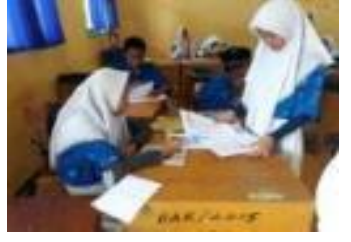

\section{Gambar 3 Diskusi Kelompok Kecil Kelas Eksperimen}

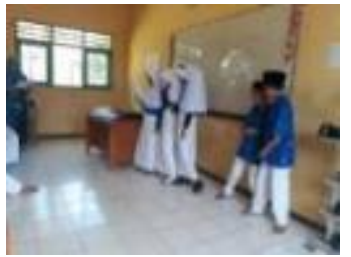

\section{Gambar 4 Diskusi Kelas Di Kelas Eksperimen}

Gambar 3 dan 4 di atas memperlihatkan siswa yang sedang berdiskusi dalam kelompok kecil yang terdiri dari 4-5 orang siswa, kemudian diskusi dalam kelompok besar yang terdiri dari semua siswa di dalam kelas tersebut.

Setelah setiap kelompok menyempaikan kesimpulan menurut kelompoknya masing-masing, selajutnya guru menanggapi kesimpulan yang dipaparkan oleh siswa dan menarik kesimpulan secara umum.

\section{PENUTUP \\ Simpulan}

Berdasarkan hasil penelitian dan pembahasan, maka dapat disimpulkan bahwa hasil belajar matematika siswa yang menggunakan pendekatan matematika realistik lebih tinggi dari hasil belajar matematikan siswa yang menggunakan pendekatan saintifik di kelas VII SMPN 14 Kota Bengkulu tahun ajaran 2017/2018. Hal ini ditunjukkan dari hasil uji-t yang dilakukan dengan bantuan SPSS diperoleh nilai sig.(2-tailed) $=0,003$ dan taraf signifikan $(\alpha)=0,05$, sehingga sig. (2-tailed) $<$ taraf signifikan $(\alpha)$ maka $\mathrm{H}_{0}$ ditolak.

\section{Saran}

Penerapan pendekatan matematika realistik harus disesuaikan dengan materi pembelajaran, karena tidak semua materi pada mata pelajaran matematika cocok dengan pendekatan matematika realistik.

\section{DAFTAR PUSTAKA}

Daryanto dan Karim. 2017. Pembelajaran Abad 21. Yogyakarta : Gava Media.

Sari, Syafdi, Hanifah

Perbandingan Hasil Belajar Matematika Siswa Menggunakan Pendekatan Matematika Realistik dan Pendekatan Saintifik Di Kelas VII SMP Negeri 14 Kota Bengkulu
Hanggara dan Suhardi. 2016. Esperimentasi Pendekatan Pembelajaran Pendidikan Matematika Realistik dan Pembelajaran Saintifik terhadap Hasil Belajar Matematika Ditinjau dari Gaya Belajar Siswa Kelas VIII SMPN 25 Batam Tahun Pelajaran 2015/2016. Jurnal Tidak Diterbitkan. Riau : Universitas Riau Kepulauan.

Herawaty, dkk. 2016. Model Pembelajaran Matematika SMP untuk Mengatasi Rendahnya Kompetensi Dasar Siswa SMP Kota Bengkulu. Bengkulu : Jurnal Pendidikan Matematika Raflesia. Vol. 1, No.01 : 39-65.

Lestari dan Yudhanegara. 2017. Penelitian pendidikan Matematika. Bandung : PT Refika Aditama.

Sudjana, Nana. 2006. Penilaian Hasil Proses Belajar Mengajar. Bandung : PT Remaja Rosdakarya.

Sugiyono. 2017. Statistik untuk Penelitian.Bandung : Alfabeta.

Pranata, Deden Rizki. 2015. Perbandingan Hasil Belajar Matematika Siswa antara Pembelajaran dengan Pendekatan Saintifik dengan Pembelajaran Konvensional di Kelas VII SMPN 11 Kota Bengkulu. Skripsi Tidak Diterbitkan. Bengkulu: Universitas Bengkulu.

Wijaya Ariyadi. 2012. Pendidikan Matematika Realistik. Yogyakarta : Graha Ilmu.

Zaini dan Marsigit. 2014. Perbandingan Keefektifan Pembelajaran Matematika dengan Pendekatan Matematika Realistik dan Konvensional Ditinjau dari Kemampuan Penalaran Dan Komunikasi Matematik Siswa. Yogyakarta : Jurnal Riset Pendidikan Matematika. Vol. 1, No. 2 : 152-163. 